\title{
Investigating the Influence of Weft Knitting Parameters on Physical and Mechanical Fabric
} Characteristics.

\author{
A. M. Aldardery ${ }^{1}$, H. A.A-Aleem ${ }^{2}$, E.A.EL-okda ${ }^{2}, \underline{\text { C.M.Al-zean }}{ }^{2}$ \\ ${ }^{1}$ Polymers metrology\& Technology Lab. National Institute of Standards. \\ ${ }^{2}$ Home Economics Dept (Textile \& Clothing). Women's college-Ain Shams University
}

\begin{abstract}
The testing of knitting fabrics before being used in the garment industry is an issue of great importance to improve the quality of the final product. This research aims tostudy the effect of knitting variables, eg. Fabric structure, loop length, yarn count, and yarn material on thickness, bursting strength and air permeability of some weft knitted fabrics. For this purpose three knitted structures (single jersey, rib1×1, interlock $1 \times 1$ ) were knitted with two levels of loop lengths, two yarn counts, and two different yarn material ( cotton100\%, cotton polyester 50/50)for each structure to produce twenty -four samples; eight samples for each structure. The findings of this study revealed that thickness and bursting strength values for interlock fabrics is generally higher than rib fabrics, and both of them are higher than single jersey fabrics, It was found that the fabrics with the same structure knitted with cotton-polyester yarns shows high bursting strength values more than the fabrics knitted with cotton yarns . It was also found that the fabrics with the same structure knitted using short loop length are thicker and gives higher fabric bursting strength values and air permeability of the fabric decreased remarkably. For the yarn count the fabrics knitted with finer yarn count are thinner, gives the lowest fabric bursting strength value while air permeability of the fabric increased. This research helpsgarments manufacturing to understand the nature of weft knitted fabrics and factors that are affected by these fabrics, which can be controlled to select a suitable raw material for the final product.
\end{abstract}

Key words: weft -knitted fabric, bursting strength, air permeability.Knittingstructure.

\section{Introduction:}

Analysis and testing of knitted fabrics are done for evaluating the quality aspects of the garments made from knitted fabrics. It helps to assess the quality of the end product,

\footnotetext{
* Corresponding author:Ca-power@hotmail.co.uk
} 
performance of the fabric during manufacturing and the end use. Recently Knitted garments have become a key component in the wardrobe of most women's. This was not a coincidence, but it was a result of the special properties which is fundamentally different from the properties of woven garments. And because it's Tough competition in the garment industry, the manufactures must begin to increase their knowledge of the properties of the knitted fabrics as new and popular textiles. Also they must take in consideration when planning the quality of knitted fabrics it is necessary to know the relations between the quality of the product and the parameters of the process. The coordination of these parameters and keeping them in proper relation makes better quality products of knitted fabricsV.Cepujnoskaet al, 1996.

The thickness of a fabric is one of its basic properties; giving information on its warmth, weight and stiffnessJ.Hu, 2008.In some cases fabric weight per unit area is used commercially as an indicator of thicknessB.Saville, 1999. The fabric with coarser yarn count and short loop length gives the higher fabric thickness and vise versaZ.Abdlmegiedet al, 2011. The effect of knit structure, relaxation processes and their interactions is highly significant on fabric thickness, although knit structure has the greatest effectN.Emirhanovaet al, 2008.

Bursting strength is the multi directional forces exerted perpendicularly on the fabric surface to break off fabricS.Mavruzet al, 2007. S. Mavruzet al, 2010.Bursting strength test for knitted fabrics gives the knitted garment producer a prediction nearby of how these fabrics will extend during end use. The effect of knit structures on the bursting strength of fabric is highly significantY. Kavuşturan, 2002. The bursting properties of knitted fabrics greatly affected with loop length, with the decrease of loop length bursting strength increasesand vise versaS.Yesminet al, 2014.Z.Abdlmegiedet al, 2011.

Air permeability is often used to evaluate and compare how the fabrics will allow the air flow to penetrate easily through them. In other words it measures the breathability of fabrics. The air permeability one of the tests that should be considered when examining how comfortable will be the fabrics during the end use, by this test the garment manufacturer will be able to decide its application. The shape and value of the pores and the inter-thread channels of the fabric has significant effect on the air permeabilityA.Olsauskiene et al, 2004.F.Çeken, 1997.Y. Kavuşturan,2002.N.Emirhanova, et al, 2008, analyzed the effects of knit structures on air permeability. 
The matter with knitted fabrics did not stop at just the testing phase, but also arrived to the existence of many researches to predict the outcome results before testingF. Marsalet al 2009.P. G. Ünalet al, 2011,S. Ertugrulet al, 2000.

\subsection{Aim of the work}

The aim of this research is to investigate the influence of knitting structure, loop length, yarn count and yarn materialon thickness, bursting strength and air permeability of weft knitted fabrics and use them as a parameters that can be controlled to reach the suitable fabrics for the end product.

\subsection{Methodology}

Experimental and comparative study.

\subsection{Search Limits}

-fabrics were knitted at El Nasr for spinning, weaving and knitting (CHOURBAGUI), Cairo, ARE.

-The physical and mechanical tests for all examined knitted fabrics were measured at the National Institute for Measurement and Calibration according to A.S.T.M standards; it is worth mentioning that the lab holds a quality certification.

\subsection{Terminology}

-weft knitting: Knitted fabrics are formed by interlocking loops of yarns. The interlocking of these loops can be done by either vertical or horizontal movement. When the yarns are introduced in a crosswise direction, at right angles to the direction of growth of the fabric, the knit is known as a weft knit.

-Single jersey: made with a complete absence of any fancy mechanism. The stitches are side by side in the same plane and show semicircular loops on the technical back and the appearance of v-shaped stitches on the front

-Rib: a knitted fabric with vertical rows of loops meshed in the opposite direction to other Wales

-Interlock: it is composed of two 1/1 ribs interlocked together with crossed sinker WalesD. J. Spencer, 2001. 


\section{Materials and Method}

Twenty-four knitted fabrics were knitted that varied in terms of blend ratio, yarn count, loop lengths, and finally the knitting structure; the selected structures were single jersey, rib $1 \times 1$, and interlock $1 \times 1$ produced using circular machine Mayer \&Cie of "juage 20, 18, 20". The experimental variables are given in table 1 .

Steps of finishing knitted samples:

1- Scouring

2- Rinsing in water and air dried

3- Half bleaching

4- Softening using suitable agent

5- Full relaxation (wet relaxation) then dried for 40 minutes at $80^{\circ} \mathrm{C}$ (dry relaxation)

Table1. Experimental variables for the twenty-four tested samples.

\begin{tabular}{|c|c|c|c|c|c|}
\hline $\begin{array}{l}\text { Fabric } \\
\text { code. }\end{array}$ & $\begin{array}{c}\text { Fabric } \\
\text { structure }\end{array}$ & Material & $\begin{array}{c}\text { Blending ratio } \\
\%\end{array}$ & $\begin{array}{l}\text { Yarn } \\
\text { count }\end{array}$ & $\begin{array}{c}\text { Stitch length } \\
\text { (m.m) }\end{array}$ \\
\hline 1 S.J & \multirow{8}{*}{ 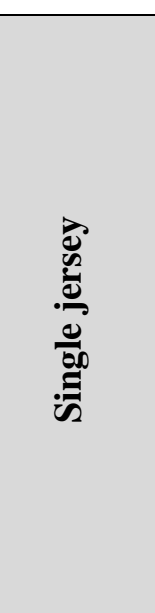 } & Cotton & 100 & 36 & 3 \\
\hline $2 \mathrm{~S} . \mathrm{J}$ & & Cotton & 100 & 36 & 3.5 \\
\hline 3 S.J & & Cotton & 100 & 30 & 3 \\
\hline 4 S.J & & Cotton & 100 & 30 & 3.5 \\
\hline 5 S.J & & Cotton/polyester & $50 / 50$ & 36 & 3 \\
\hline 6 S.J & & Cotton/polyester & $50 / 50$ & 36 & 3.5 \\
\hline 7 S.J & & Cotton/polyester & $50 / 50$ & 30 & 3 \\
\hline 8 S.J & & Cotton/polyester & $50 / 50$ & 30 & 3.5 \\
\hline $1 \mathrm{R}$ & \multirow{7}{*}{ 卷 } & Cotton & 100 & 36 & 2.85 \\
\hline $2 \mathrm{R}$ & & Cotton & 100 & 36 & 3 \\
\hline $3 \mathrm{R}$ & & Cotton & 100 & 30 & 2.85 \\
\hline $4 \mathrm{R}$ & & Cotton & 100 & 30 & 3 \\
\hline $5 \mathrm{R}$ & & Cotton/polyester & $50 / 50$ & 36 & 2.85 \\
\hline $6 \mathrm{R}$ & & Cotton/polyester & $50 / 50$ & 36 & 3 \\
\hline $7 \mathrm{R}$ & & Cotton/polyester & $50 / 50$ & 30 & 2.85 \\
\hline
\end{tabular}




\begin{tabular}{|c|c|c|c|c|c|}
\hline $8 \mathrm{R}$ & & Cotton/polyester & $50 / 50$ & 30 & 3 \\
\hline 1 I.L & \multirow{8}{*}{ 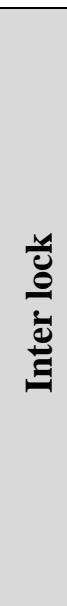 } & Cotton & 100 & 36 & 2 \\
\hline 2 I.L & & Cotton & 100 & 36 & 2.25 \\
\hline 3 I.L & & Cotton & 100 & 30 & 2 \\
\hline 4 I.L & & Cotton & 100 & 30 & 2.25 \\
\hline 5 I.L & & Cotton/polyester & $50 / 50$ & 36 & 2 \\
\hline 6 I.L & & Cotton/polyester & $50 / 50$ & 36 & 2.25 \\
\hline 7 I.L & & Cotton/polyester & $50 / 50$ & 30 & 2 \\
\hline 8 I.L & & Cotton/polyester & $50 / 50$ & 30 & 2.25 \\
\hline $\mathrm{S} . \mathrm{J}=\mathrm{Singl}$ & & & terlock & & \\
\hline
\end{tabular}

\section{- The physical properties test:}

- Air permeability according to ASTM D 737-04(2012)

-Thickness according to ASTM D1777-96(2011)

-Fabric weight according to ASTM D3776/ D3776M-09a

\section{- The mechanical properties test:}

-Burst strength according to ASTM D 3787-07(2001)

The Average results for Tested Samples are shown in table 2 
Table2. The Average results for Tested Samples

\begin{tabular}{|c|c|c|c|c|c|c|c|c|}
\hline $\begin{array}{c}\text { Fabric } \\
\text { code. }\end{array}$ & $\begin{array}{c}\text { Fabric } \\
\text { structure }\end{array}$ & $\begin{array}{l}\text { Course } \\
\text { per } \mathrm{cm}\end{array}$ & $\begin{array}{l}\text { Wales } \\
\text { per } \mathrm{cm}\end{array}$ & $\begin{array}{c}\text { Stitch } \\
\text { Density }\end{array}$ & $\begin{array}{c}\text { Fabric } \\
\text { Weight } \\
\mathrm{g} / \mathrm{m}^{2}\end{array}$ & $\begin{array}{c}\text { Thickness/ } \\
\mathrm{mm}\end{array}$ & $\begin{array}{c}\text { Air } \\
\text { permeability/ } \\
\mathrm{Cm} 3 / \mathrm{cm} 2 / \mathrm{sec}\end{array}$ & $\begin{array}{c}\text { Bursting } \\
\text { strength } \\
\mathrm{n} / \mathrm{cm} 2\end{array}$ \\
\hline 1 S.J & \multirow{8}{*}{ 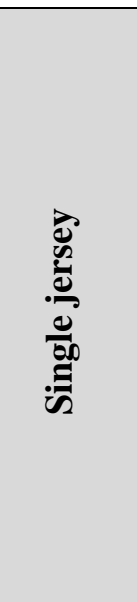 } & 16 & 16 & 256 & 105 & 0.4 & 109 & 264 \\
\hline 2 S.J & & 12 & 14 & 168 & 86 & 0.4 & 120 & 234 \\
\hline 3 S.J & & 16 & 14 & 224 & 142 & 0.5 & 102 & 298 \\
\hline 4 S.J & & 12 & 14 & 168 & 115 & 0.5 & 111 & 246 \\
\hline 5 S.J & & 18 & 16 & 288 & 109 & 0.4 & 140 & 427 \\
\hline 6 S.J & & 12 & 14 & 168 & 91 & 0.4 & 161 & 344 \\
\hline 7 S.J & & 18 & 14 & 252 & 136 & 0.5 & 112 & 487 \\
\hline 8 S.J & & 12 & 14 & 168 & 113 & 0.5 & 124 & 370 \\
\hline $1 \mathrm{R}$ & \multirow{8}{*}{ है } & 16 & 12 & 192 & 183 & 0.7 & 90.5 & 353 \\
\hline $2 \mathrm{R}$ & & 14 & 12 & 168 & 135 & 0.6 & 109 & 255 \\
\hline $3 \mathrm{R}$ & & 14 & 12 & 168 & 177 & 0.8 & 61.3 & 354 \\
\hline $4 R$ & & 16 & 12 & 192 & 188 & 0.7 & 69.5 & 282 \\
\hline $5 \mathrm{R}$ & & 14 & 12 & 168 & 157 & 0.6 & 84.3 & 457 \\
\hline $6 \mathrm{R}$ & & 14 & 12 & 168 & 142 & 0.6 & 104 & 369 \\
\hline $7 R$ & & 14 & 12 & 168 & 186 & 0.7 & 81 & 500 \\
\hline $8 \mathrm{R}$ & & 14 & 12 & 168 & 130 & 0.7 & 90 & 490 \\
\hline $1 \mathrm{I} . \mathrm{L}$ & \multirow{8}{*}{ } & 10 & 14 & 140 & 150 & 0.8 & 61.8 & 389 \\
\hline 2 I.L & & 10 & 16 & 160 & 175 & 0.7 & 76 & 338 \\
\hline 3 I.L & & 12 & 14 & 168 & 217 & 0.9 & 45.6 & 430 \\
\hline 4 I.L & & 10 & 14 & 140 & 199 & 0.9 & 47.8 & 350 \\
\hline 5 I.L & & 10 & 16 & 160 & 179 & 0.7 & 71.4 & 620 \\
\hline $6 \mathrm{I} . \mathrm{L}$ & & 10 & 14 & 140 & 168 & 0.7 & 86.5 & 608 \\
\hline 7 I.L & & 12 & 14 & 168 & 226 & 0.8 & 51 & 650 \\
\hline $8 \mathrm{I} . \mathrm{L}$ & & 10 & 14 & 140 & 205 & 0.8 & 74.9 & 634 \\
\hline$S . J=S$ & rsey & & & & - Int & & & \\
\hline
\end{tabular}




\section{Results and Discussion}

\subsection{Fabric thickness}

\subsubsection{Effect of knitting Structure on fabric thickness}

It was noticed that changing the knitting structure has a strong effect on the thickness of the fabric. In figure 1, the test results which indicate that the interlock fabrics is generally thicker than rib fabrics, and both of them are thicker than single jersey fabrics

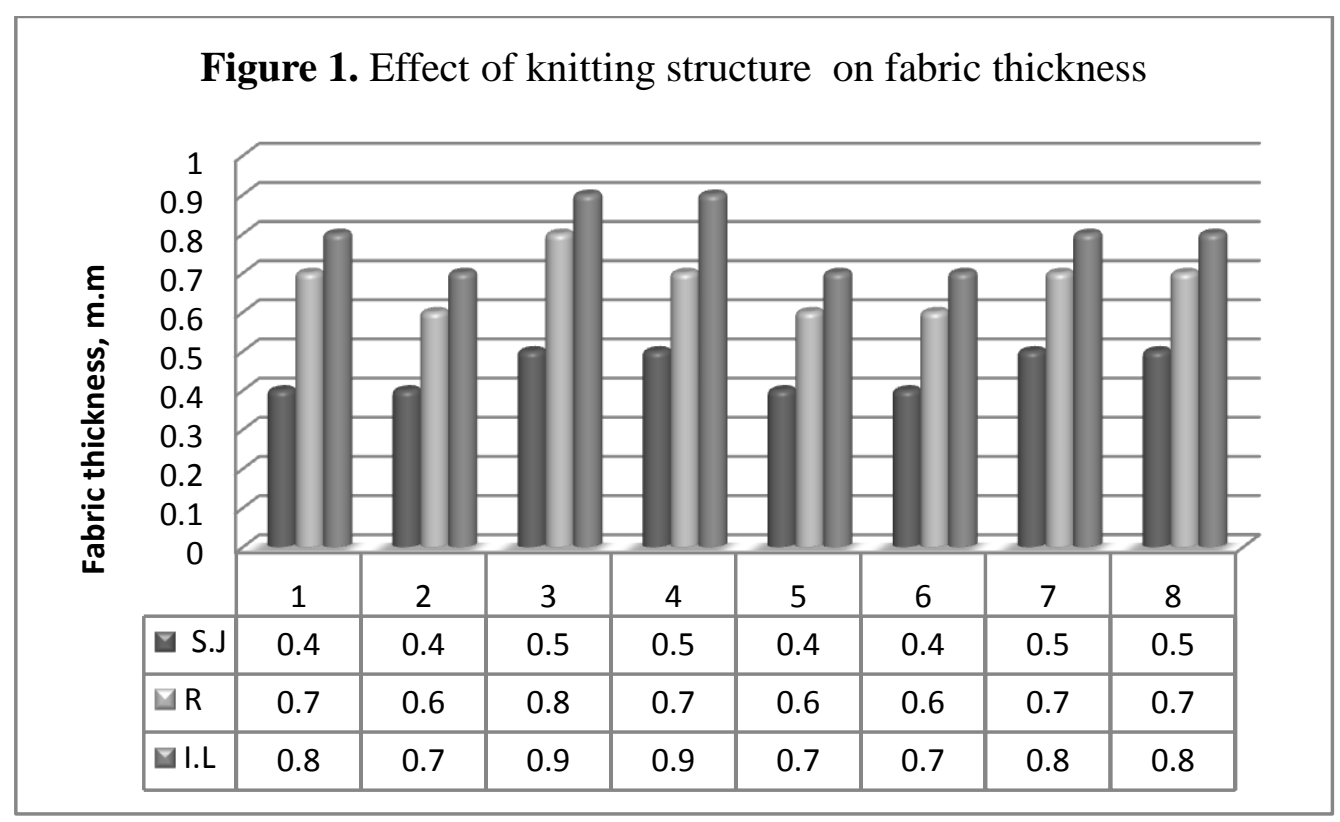

\subsubsection{Effect of yarn type and yarn count on fabric thickness}

Changing of blend ratio didn't effect on fabric thickness in each structure. While the relation between the fabric thickness and the yarn count According to figures 2, 3 and 4 is directly proportional, in other words the fabric with coarser yarn count gives the higher fabric thickness. 

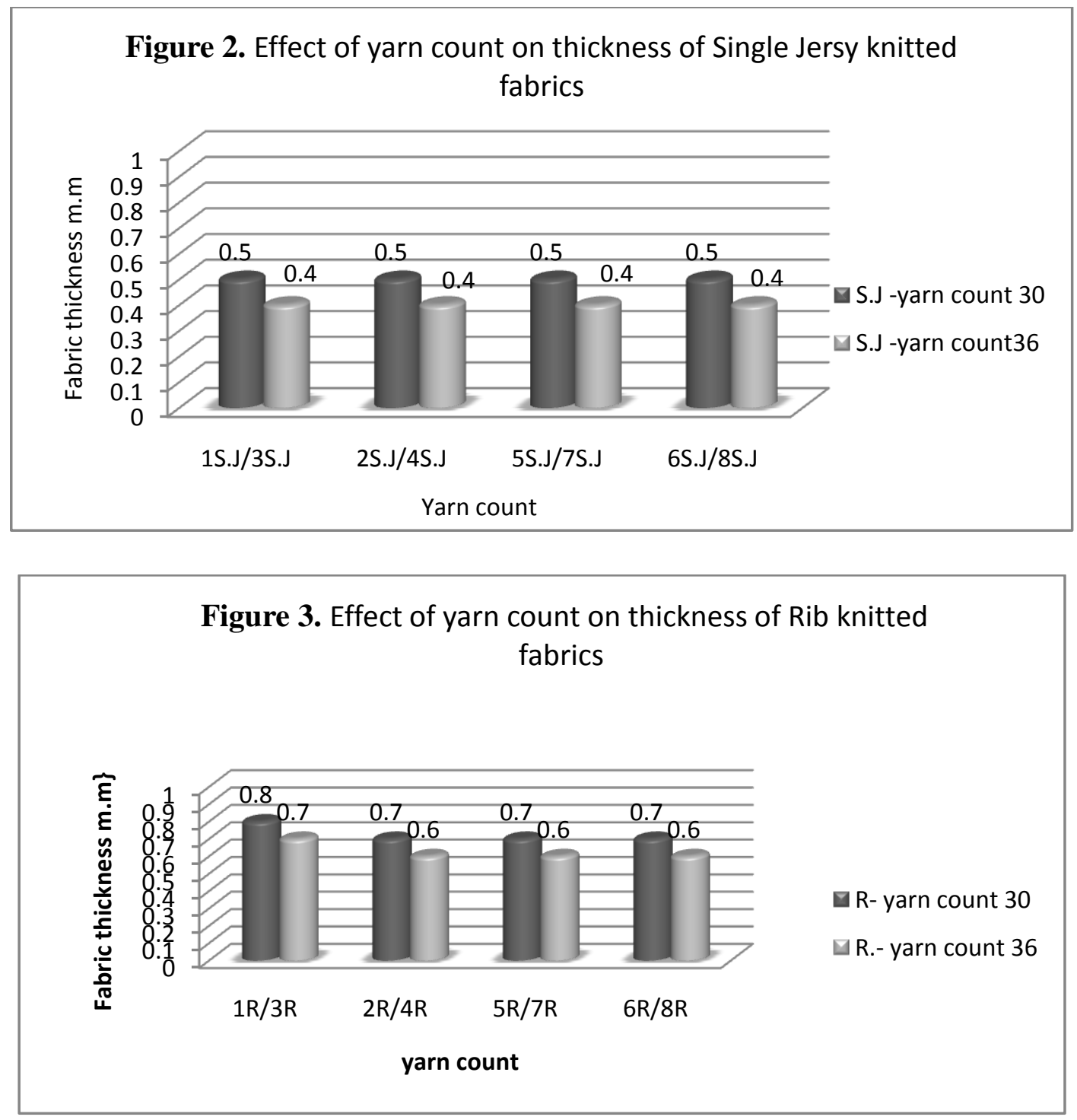

Figure 4. Effect of yarn count on thickness of interlock knitted fabrics

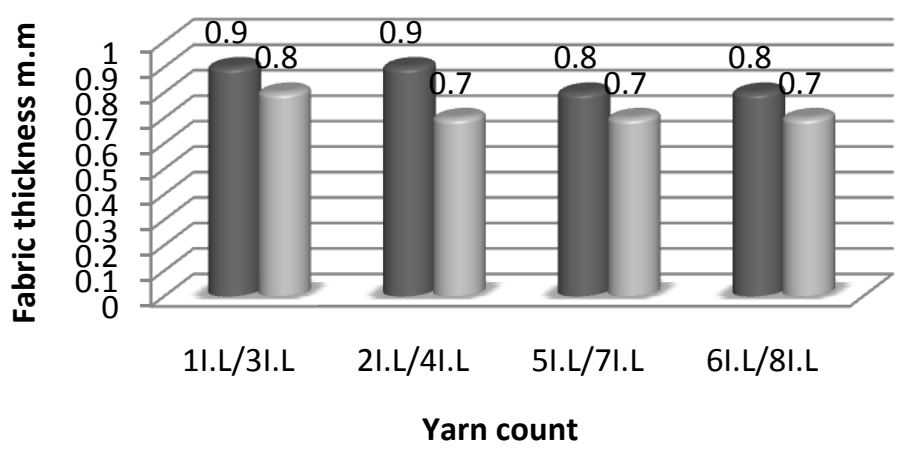

口I.L -yarn count30 $\square$ I.L-yarn count36 


\subsubsection{Effect of loop length on fabric thickness}

It is clear from figure 5 that changing loop length didn't affect the thickness of the single jersey fabrics. On the other hand, the results of rib and interlock fabrics are illustrated in figures 6 and 7; which show that the relation between the thickness and the loop length is an inversely proportional, in other words the fabric with short loop length gives the higher fabric thickness.
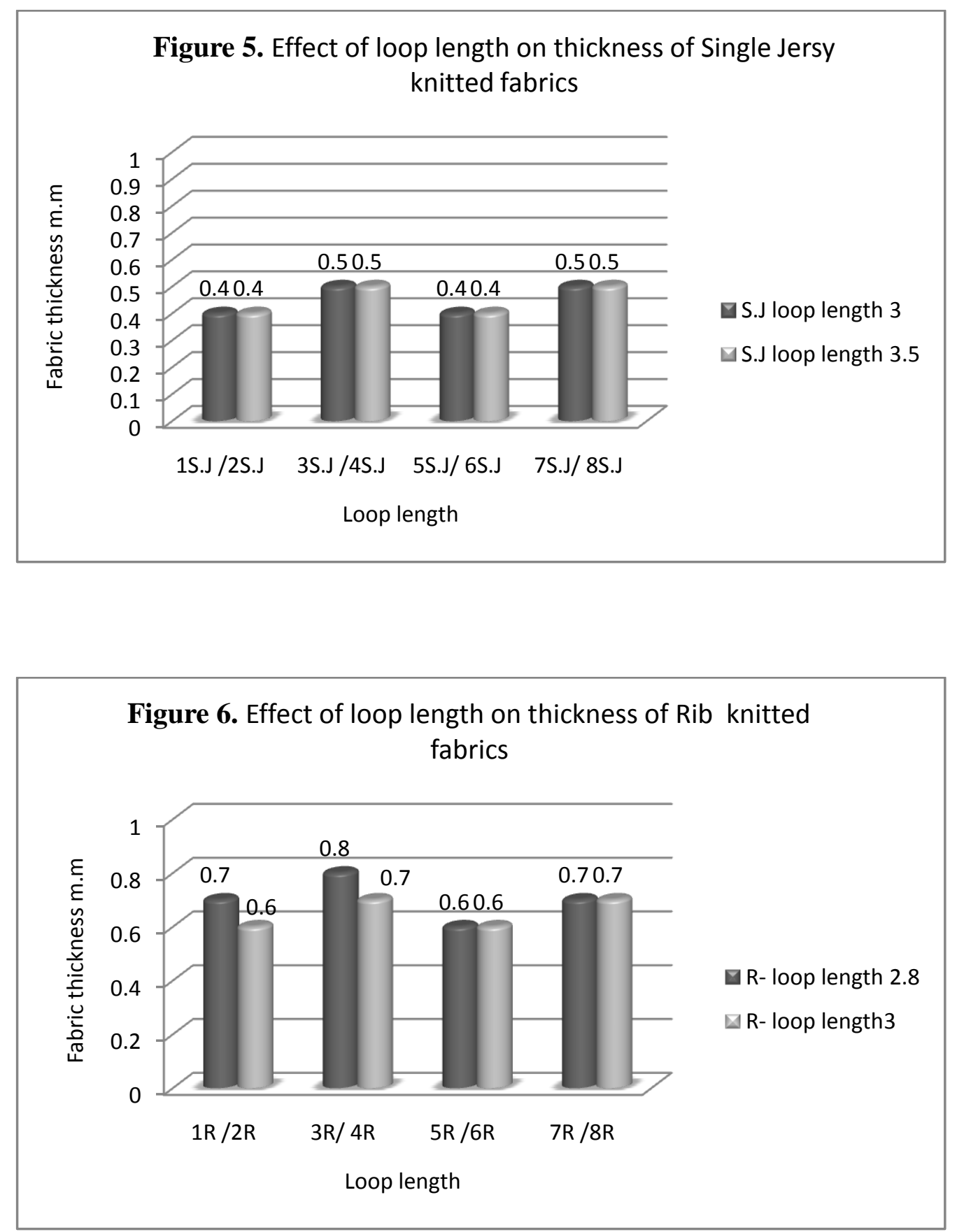


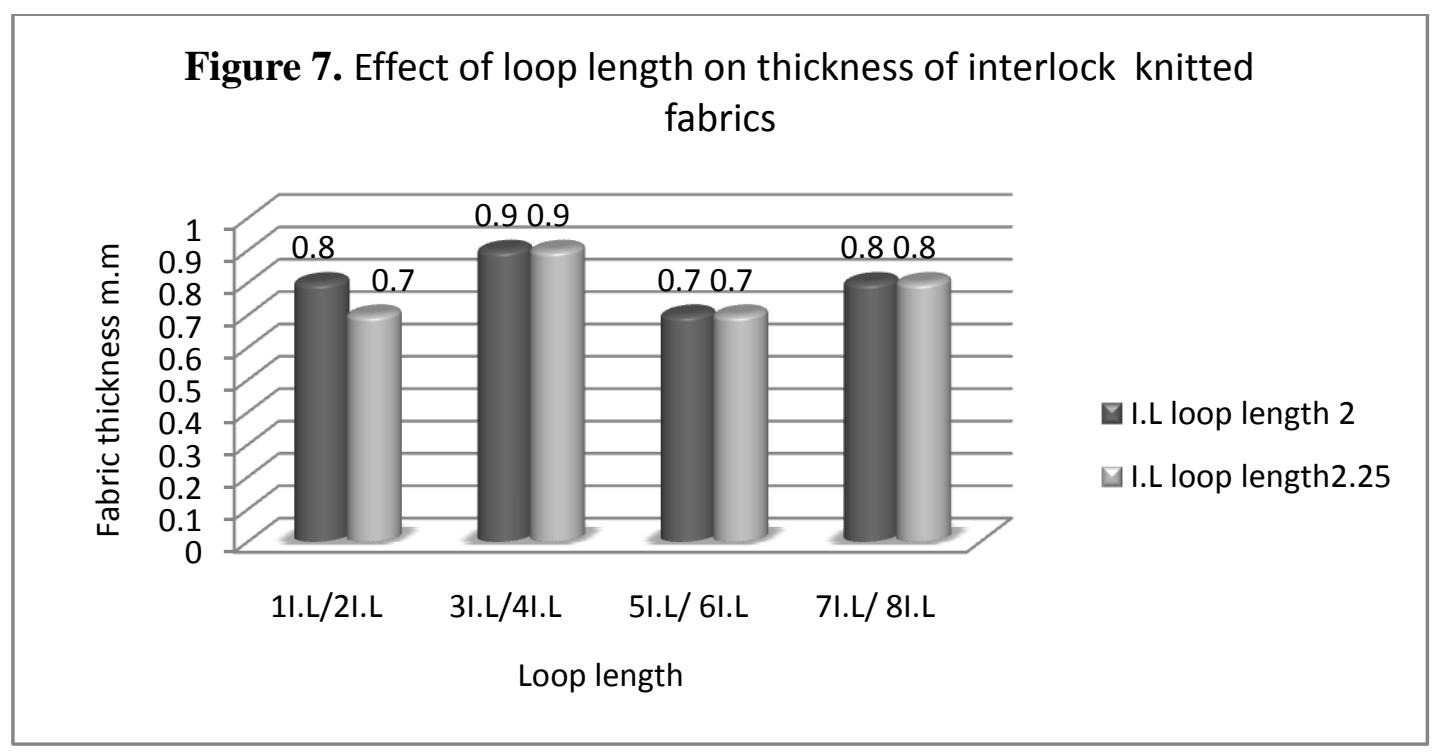

\subsection{Bursting strength of knitted fabrics}

\subsubsection{Effect of knitting structure on bursting strength}

The test results that are illustrated in figure 8 indicate that the maximum bursting strength occurred in interlock fabrics and in the case of single jersey fabrics low bursting strength values were obtained. This is because of the difference of fabric structure and fabric aerial density and lower tightness factor of single jersey. It was also noticed that Knitted Fabrics with lowest values of bursting strength will extend less but more easily.

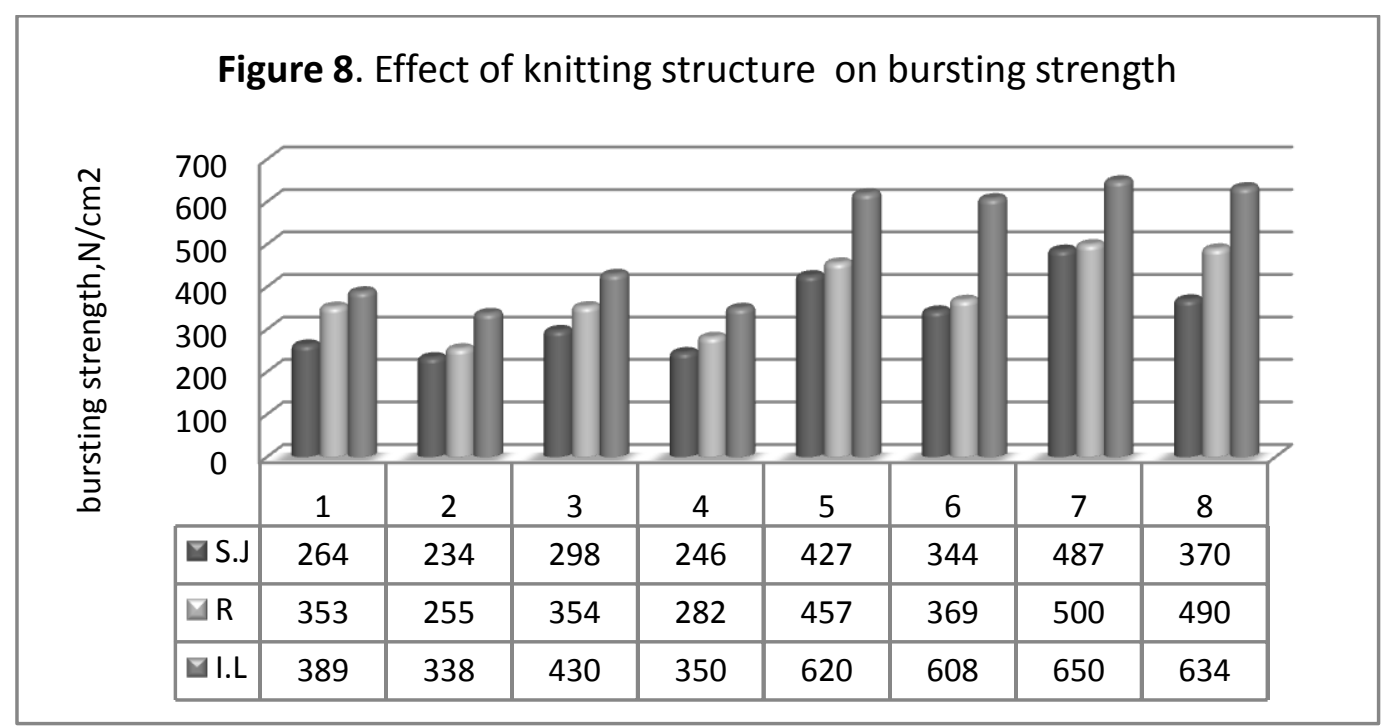




\subsubsection{Effect of yarn type on bursting strength.}

As illustrated in Figures 9, 10 and 11, the fabrics which were produced from blended fibers [cotton/polyester 50/50] is generally higher bursting strength than the knitted fabrics which were produced from $100 \%$ cotton fibers, as might be expected since polyester yarns have higher strength than cotton yarn.
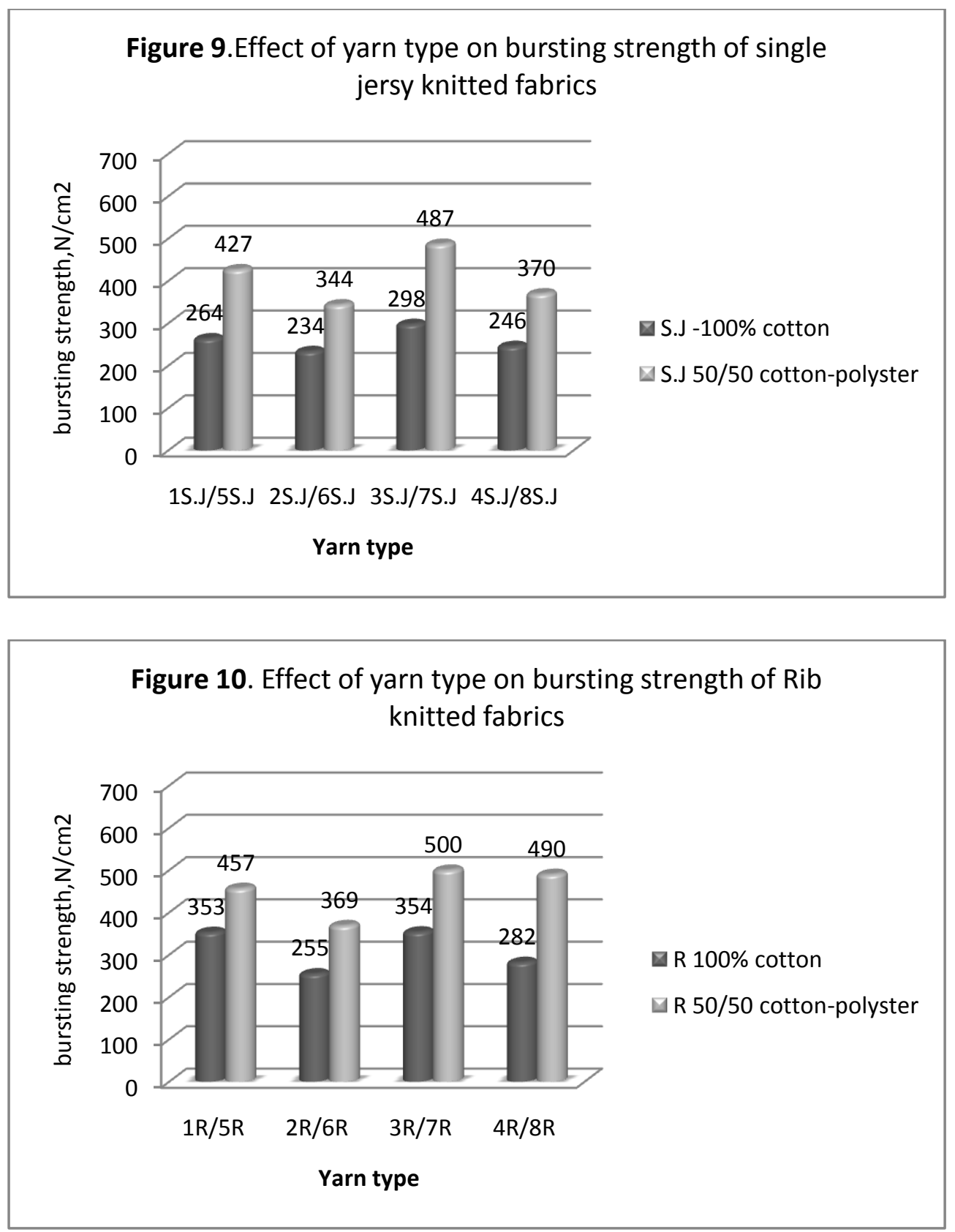


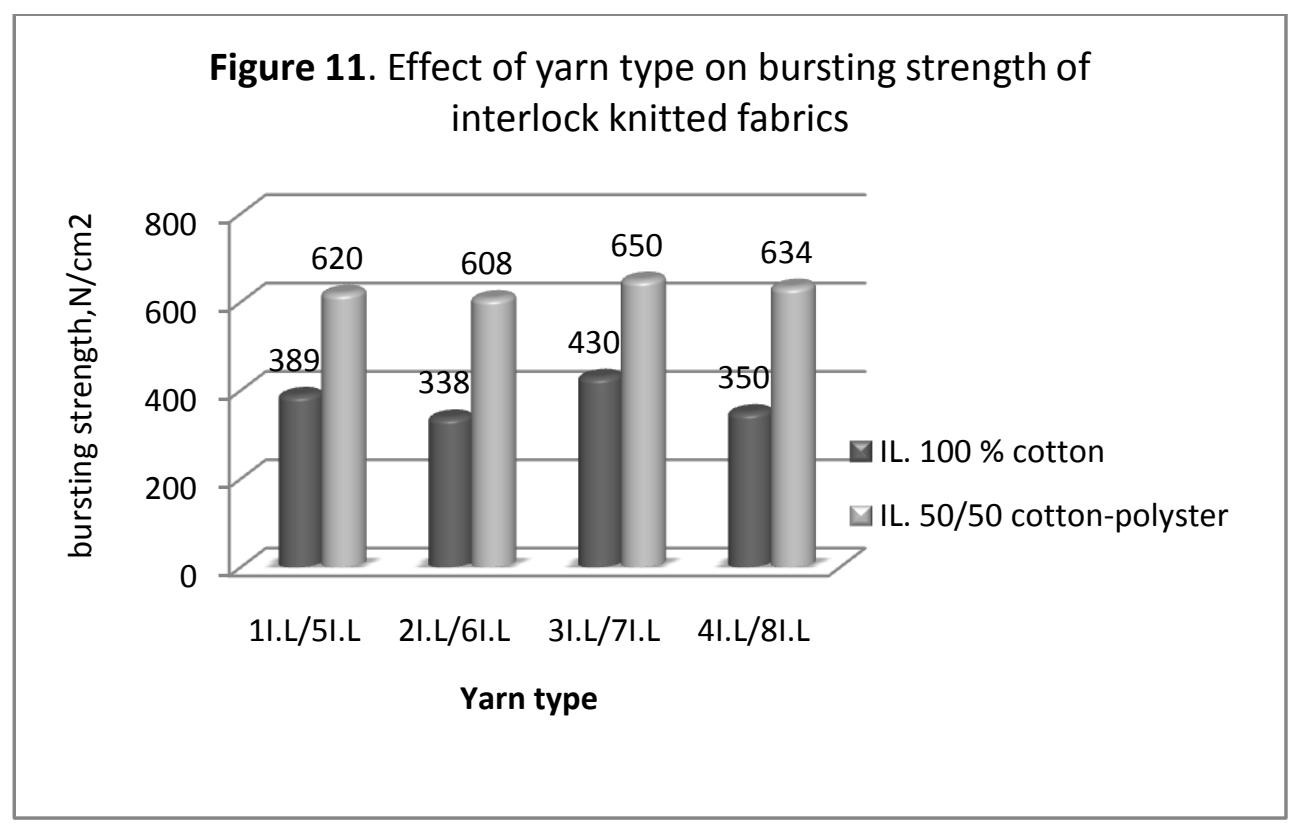

\subsubsection{Effect of loop length on bursting strength}

Close investigation of figures 12,13, 14 clarifies that the relationship between loop lengths and bursting strength are inversely proportional, In other words as the loop length in the same knitting structure increased, the bursting strength value decreased and vise versa.

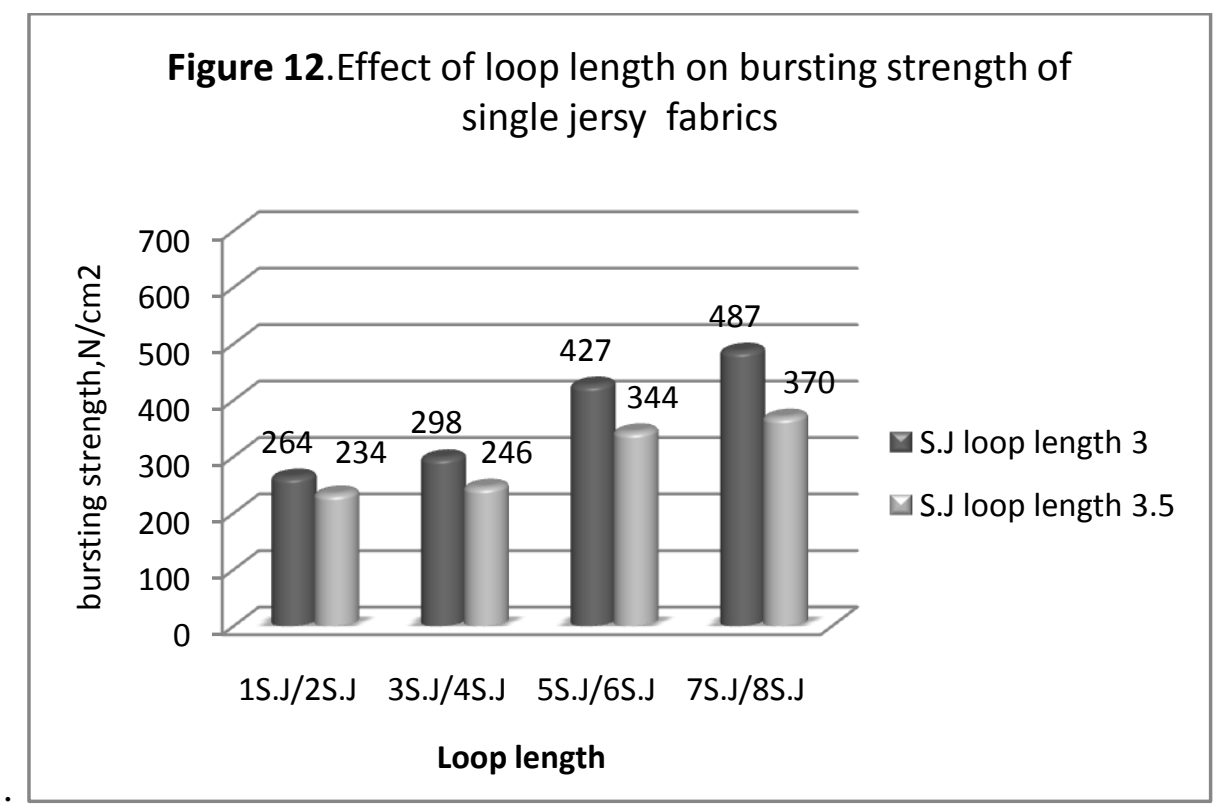



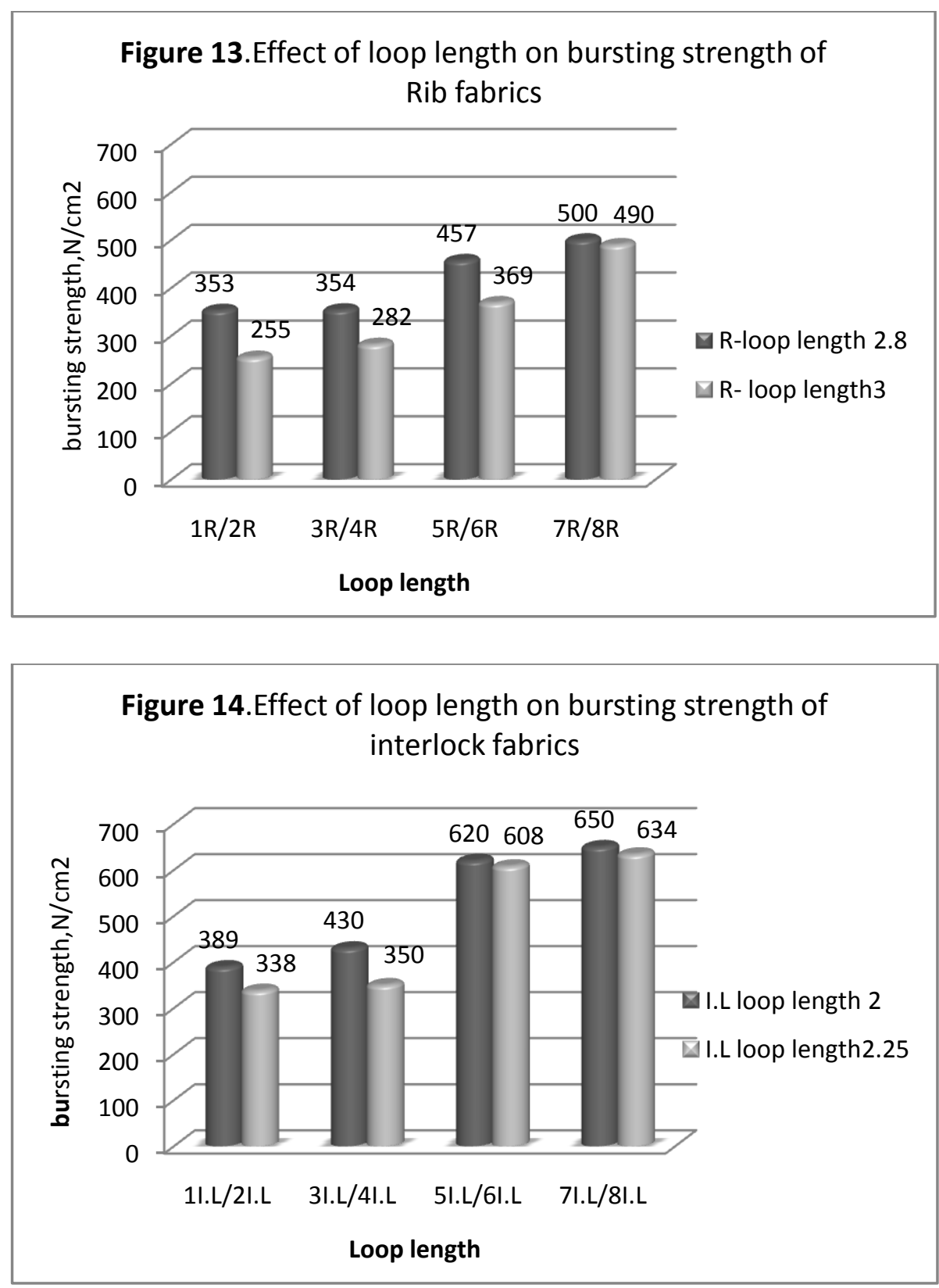

\subsubsection{Effect of yarn count on bursting strength}

Figures 15, 16, 17 shows the test results which indicate that there is a direct proportional relation between the bursting strength and the yarn count for the three knitted structures. In the three knitted fabrics the fabric with coarser yarn count gives the higher fabric bursting strength value. 

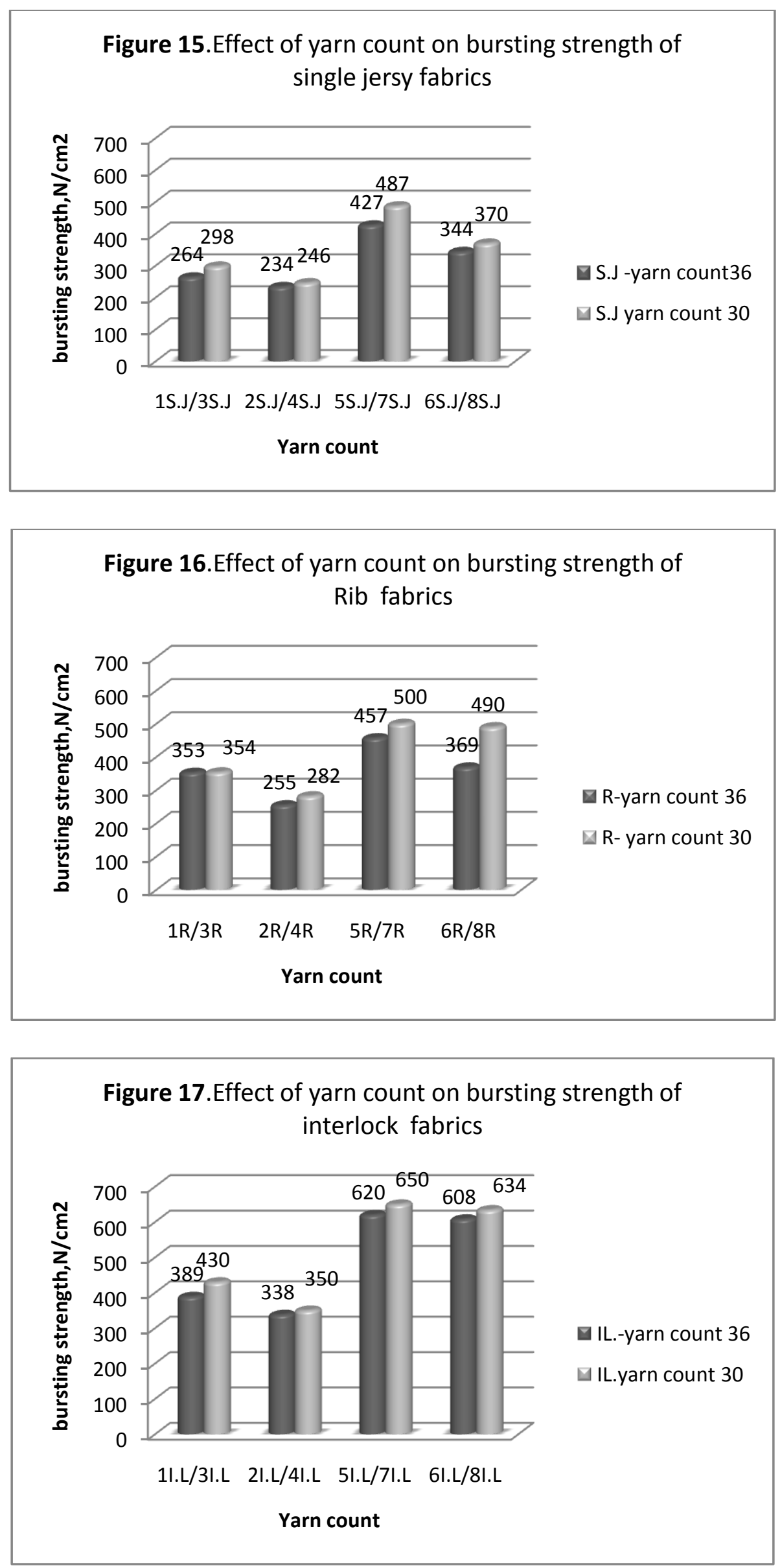


\subsection{Air permeability}

\subsubsection{Effect of knitting structure on fabric air permeability}

In this study Single jersey fabrics showed higher results in air permeability values, while the air permeability values for the rib and interlock fabrics were lessas shown in figure 18, the knitting structure was the main reason of these results. The knitting structure of the interlock and rib fabrics is getting tighter and theporous are getting smaller; therefore, the value of air permeability decreases.

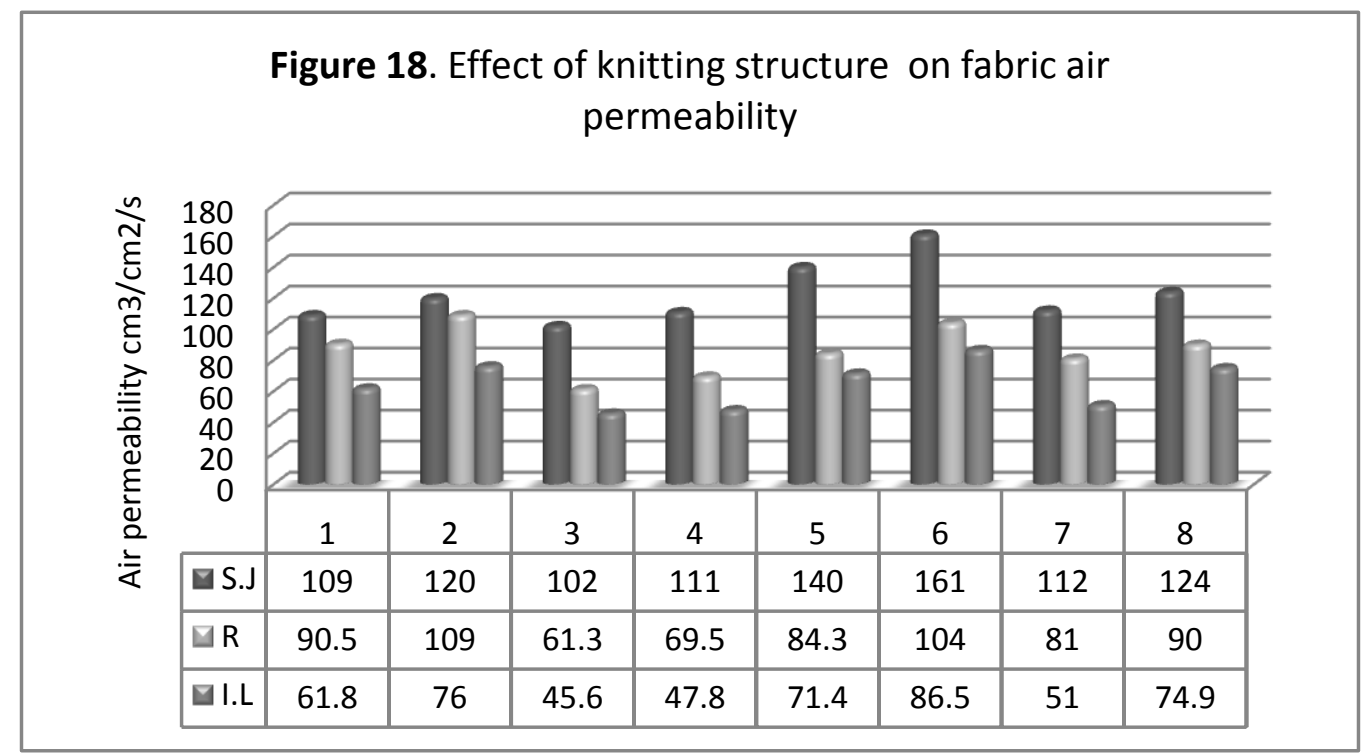

\subsubsection{Effect of yarn type and yarn count on fabric air permeability.}

The relation between the air permeability and the yarn count is directly proportional, in other words the fabrics knitted with finer yarn count gives the higher air permeability values, while yarn type has a slight different effect on air permeability values, this is shown in figures 19 , 20 and 21 

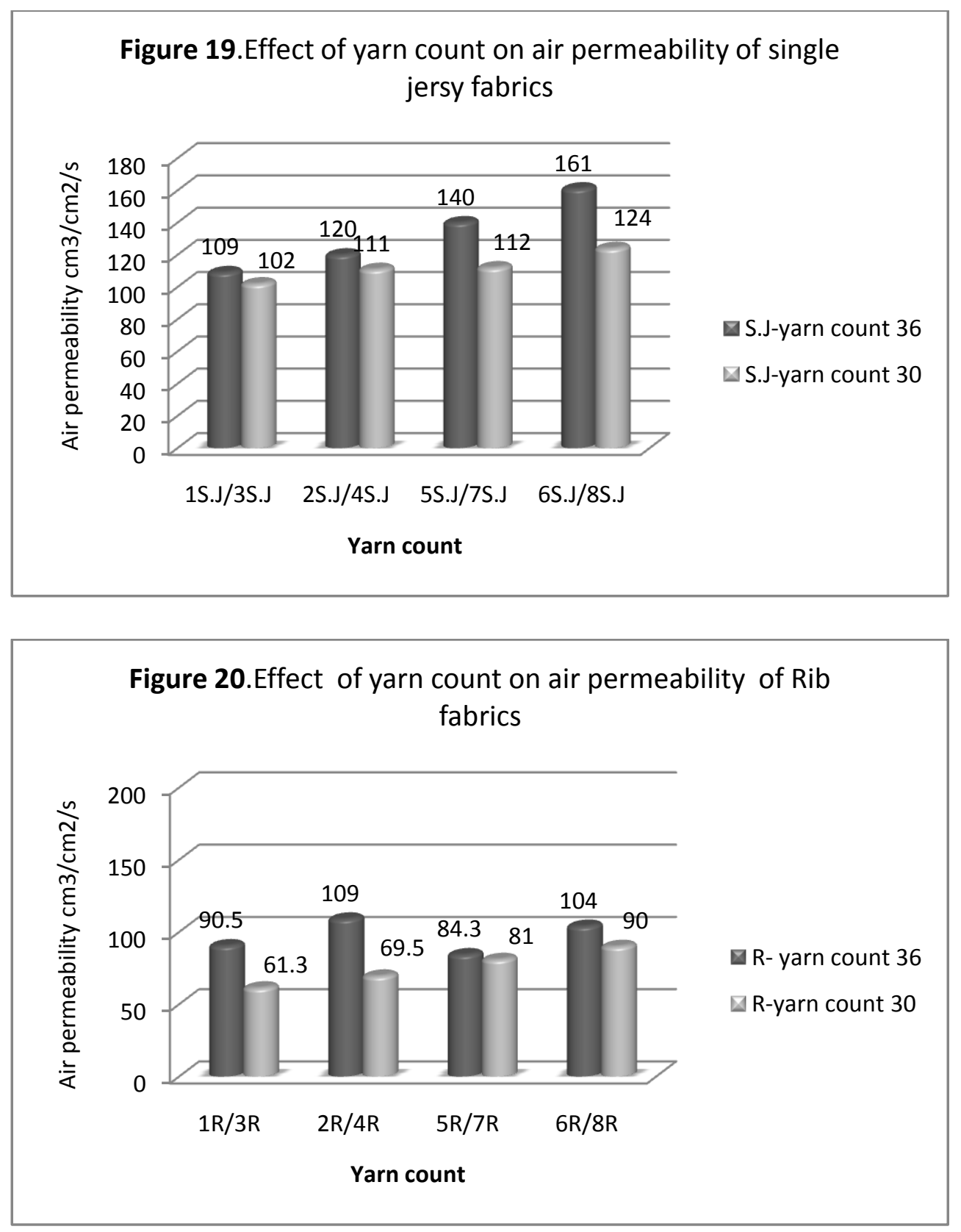

Figure 21.Effect of yarn count on air permeability of interlock fabrics

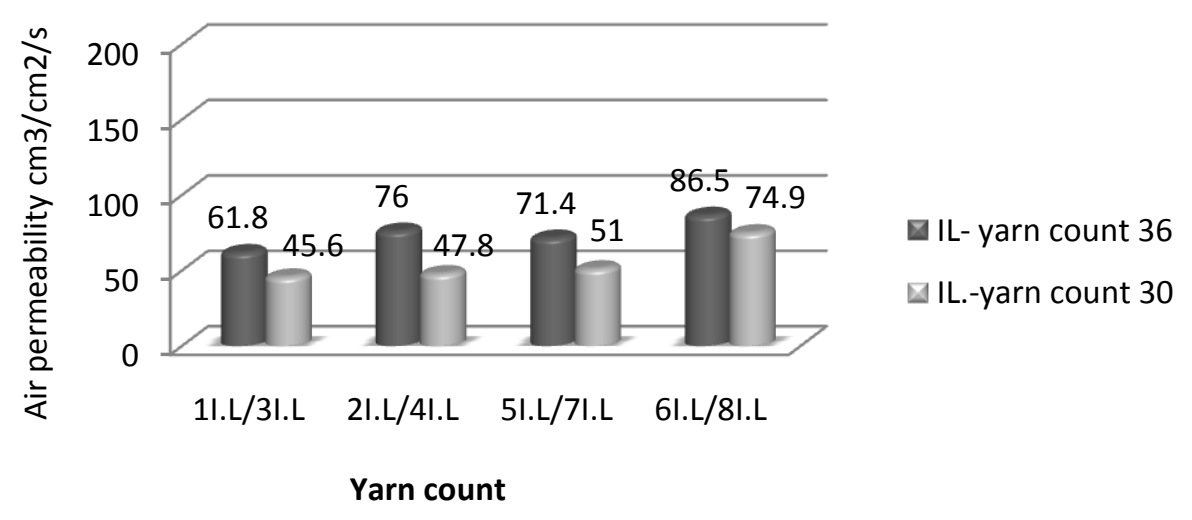




\subsubsection{Effect of loop length on fabric air permeability}

The test results as illustrated in Figures 22, 23 and 24 indicate that, in all samples, as the loop length was increased, the air permeability of the fabric increases remarkably. This means that the relation between the air permeability and the loop length for the three knitted structures is directly proportional.
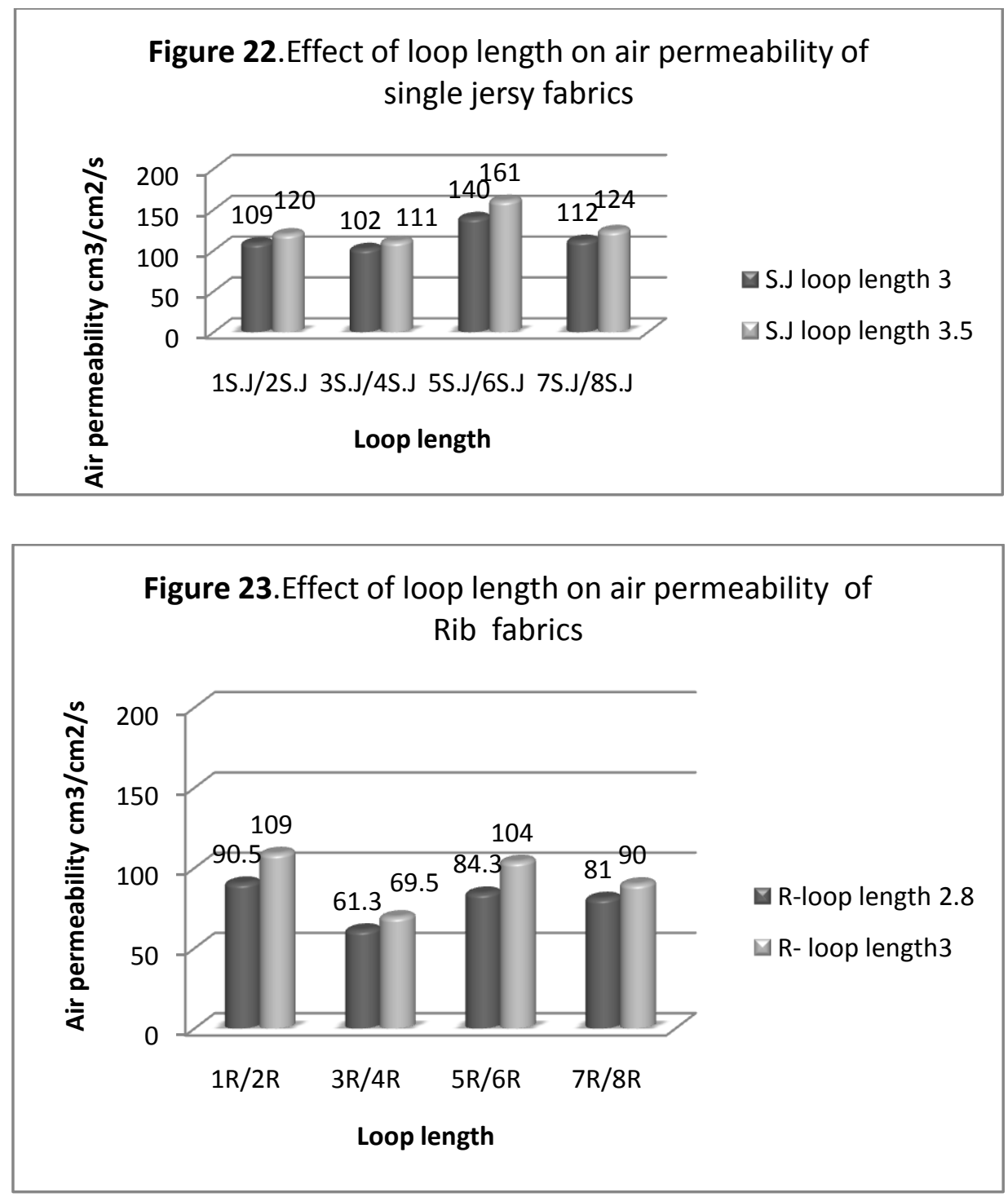


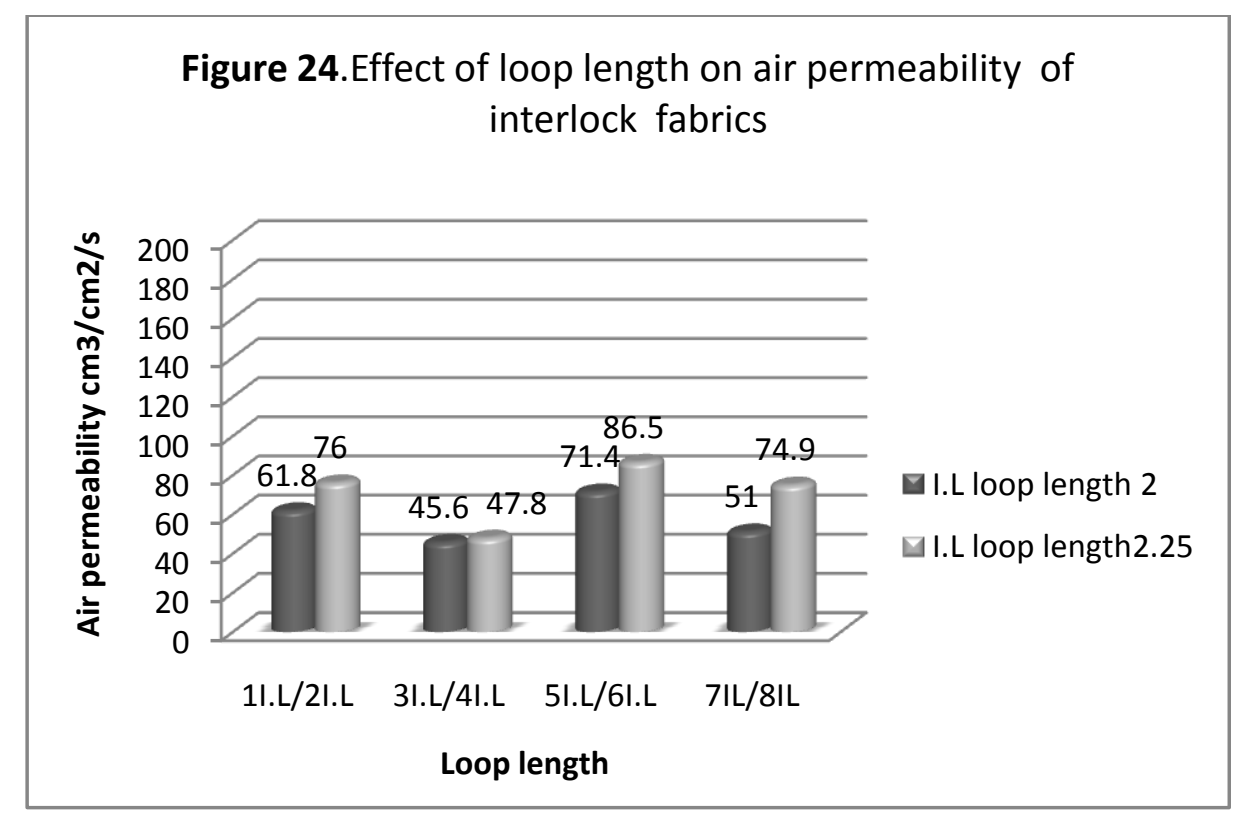

\section{Conclusion}

From the present study we can conclude that the knitting structure hasa significant impact on fabric thickness, it was found that double knitted fabrics such as interlock and rib fabrics are thicker much more than single knitted fabrics such as single jersey fabrics.

Yarn count and loop length are another parameters that can be controlled to increase or decrease the thickness values, by using coarser or fine yarns and short or long loop length.

For the fabric bursting strength it was found that double knitted fabrics with coarser yarn counts and shorter loop length can extend much more than single knitted fabrics, but in case the using of a single knitted fabric is essential, it will be useful to use coarser yarn count and shorter stitches as possible. Yarn type is another parameter that can be controlled to increase the bursting strength values, by using yarns with higher strength.

For the air permeability the single knitted fabrics has the highest air permeability, the highest course count yarns has the lowest air permeability values. Therefore, raising the stitch length leads to a looser surface on the fabric, thereby increasing the air permeability.

By testing the fabrics the garments manufacturercan use the results in two ways, one of them to determine the appropriate use, the other to know the parameters that can be changed to reach the appropriate fabrics.There still a need for more researchesthat studymoretypes of yarns, blending ratio and knitting structures. And it will be very useful if there are simple tests to evaluatefabric characteristics, eg. Fabric weight, thickness, shear, drape, and stretch to able the garments manufacturerto do it them self's in their work area. 


\section{References}

A.Olsauskiene, R. Milasıus, Integrated Fabric Firmness Factor as a Criterion of Air Permeability Designing. Proc. $2^{\text {nd }}$ International Textile Clothing \& Design

Conference,(2004).

B.P.Saville, Physical Testing Of Textiles, Woodhead Publishing Limited in association with The Textile Institute,(1999).

D. J. Spencer, Knitting Technology, Third edition, Woodhead publishing limited, 2001.

F.Çeken, An Investigation About Air Permeability of Wool/Polyester and Wool/Acrylic Knitted Fabrics, TekstilveKonfeksiyon, , 2, pp.111-115 (1997).

F. Marsal, D. Palet, L.Indrie, M. Ratiu, Aspect Prediction Of The Knitted Fabrics From The Yarn Properties, International scientific conference, Oradea,(2009).

J. HU, Fabric testing, Wood head Publishing Limited in association with The Textile Institute, (2008).

N.Emirhanova, Y.Kavusturan, Effects of Knit Structure on the Dimensional and Physical Properties of Winter OuterwearKnitted Fabrics, FIBRES \& TEXTILES in Eastern Europe, Vol. 16, No. 2 April / June (2008)

P. G. Ünal, M. E. Üreyen, D. M.Armakan, Predicting Bursting Strength Of Plain Knitted Fabrics Using Ann,Conference: ICAART 2010 - Proceedings of the International Conference on Agents and Artificial Intelligence, Volume 1 - Artificial Intelligence, Valencia, Spain, January 22-24, (2010).

S. Ertugrul, N. Ucar, Predicting Bursting Strength of Cotton Plain Knitted Fabrics Using Intelligent Techniques, Textile Research Journal, October (2000).

S. Mavruz, R.T.Ogulata, Statistical Investigation of Properties of Knitted Fabrics Made of Ring and Compact Yarns, Journal of Knitting World, pp. 60-65, (inTurkish), September/October, (2007).

S. Mavruz, R.T.Ogulata, Taguchi Approach for the Optimisation of the Bursting Strength of Knitted Fabrics,Fibres\& Textiles in Eastern Europe, Vol. 18, No. 2 (79) pp. 78-83(2010).

Standard Test Method for Air Permeability of Textile Fabrics according to ASTM D 73704(2012)

Standard Test Method for Thickness of Textile Materials according to ASTM D1777 96(2011) 
Standard Test Method for Mass Per Unit Area (Weight) of Fabric according to ASTM D3776/ D3776M-09a

Standard Test Method for Burst strength/n/cm2 according to ASTM D 3787-07(2001)

S.Yesmin, M.Hasan, M.S.Miah, F.Momotaz,M.A.idris and R.Hasan, Effect of Stitch Length and Fabric Constructions on Dimensional and Mechanical Properties of Knitted Fabrics, World Applied Sciences Journal 32 (9):, 2014 ISSN 1818 (1991-1995)

V. Cepujnoska, S. Cortoseva., Optimization Of The Processing Parameters of The Rib Knitted Fabrics, bulletin of the chemists and technologists of Macedonia, vol.15 No.2 pp.101111,( 1996).

Y.Kavuşturan, The Effects of Some Knit Structures on the Fabric Properties in Acrylic Weft Knitted Outerwear Fabrics,TekstilMaraton, , pp. 40-46(2002).

Z. M. Abdel Megeid, M. Al-bakry and M. Ezzat,The Influence Of Stitch Length Of Weft Knitted Fabrics On The Sewability, Journal of American Science, (2011). 


\section{الملخص باللفة العربية}

دراسة تأثير بعض متفيرات انتاج أقمشه تريكو اللحمه على خواصها الطبيعية والميكانيكية

عباس محمد الارديرى 1، هبه الله على عبد العليم²، إيناس عبد القادر العقةّ2، كامليا موسى الزين 2

$$
1
$$

$$
\text { جامعة عين شمس-كليه البنات_قسم الأقتصاد المنزلى (ملابس ونسيج) }
$$

إن أختبار أقشة التريكو قبل أستخدامها فى صناعة الملابس هو أمر هام لرفع كفاءة المنتج الملبسى ـ فى هذا البحث تم

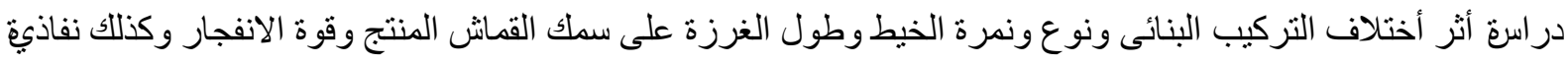
الهو اء ولتحقيق هذا الهدف تم غزل 24 عينة بثلاث تر اكيب بنائيه هى سنجل جيرسى ،ريب،و انترلوك وفى كل تركيب بنائى تم تغيير طول الغرزة ونوع ونمرة الخيط وبعد أجر اء أختبار ات سمك القماش وقوة الأنفجار ونفاذية الهو اء وجد أنة : - يختلف سمك القماش بشكل ملحوظ بأختلاف التركيب البنائى حيث وجد أن أقشش الأنترلوك و الريب هى أكثر سمكاً من أقمشة السنجل جيرسى. و فى التركيب البنائى الواحد وجد أنة كلما قصر طول الغرزة المستخدمة وقلت نمرة الخيطز اد السمك.

ـ تأثرت قوة الانفجار بشكل ملحوظ باختلاف التركيب البنائى حيث أظهر الأنترلوك أعلى النتائج بينما سجل السنجل جيرسى اقل النتائج ـ وبمقارنة نتائج التركيب البنائى الو احد وجد أن استخدام خيط البولى استر يزيد بشكل ملحوظ من قوة الانفجار كما وجدت علاقق عكسيّ بين قوة الانفجار وطول الغرزة بمعنى أنه كلما قل طول الغرزة زادت قوة الأفجار و العكس صحيح.

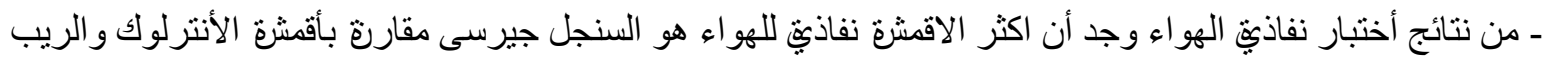
كما ان ثأثيرنمرة الخيط على نفاذية الهو اء فى التركيب البنائى الو احد هو تأثير طردى بعنى انه كلما زادت نمرة الخيط زادت نفاذية الهو اء كما وجد أيضا انه كلما قل طول الغرزة قلت نفاذيه الهو اء بشكل ملحوظ.

يساعد هذا البحث منتجى الملابس الجاهزة فى فهم طبيع ة بعض أقشة نريكو اللحمة و العو امل التى تتأثر بها هذة الأقشة و التى يمكن التحكم فيها للوصول الى الخام ة المناسبة للمنتج النهائى . على سبيل المثال فى حال ة الحاجة الى خامة ذات

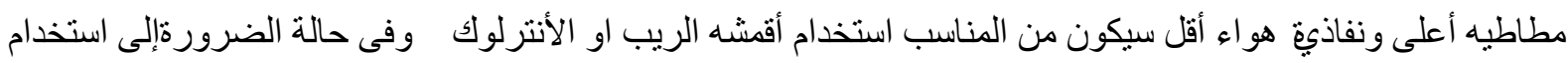
أقششة السنجل جيرسيسيكون من المناسب تقليل طول الغرزة و نمرة الخيط. 